\title{
THE INFLUENCE OF AGE AND SEASON ON THE ACTIVITY OF THE TESTES AND EPIDIDYMIDES OF THE FALLOW DEER, DAMA DAMA
}

\author{
R. E. GHAPLIN* AND R. W. G. WHITE \\ Anatomy School, University of Cambridge, Downing Street, Cambridge, and \\ Zoology Department, Chelsea College, London, S.W.10 \\ (Received 15th Fuly 1971, accepted 5th November 1971)
}

\begin{abstract}
Summary. The growth and spermatogenic activity of the testes and epididymides of fallow deer of determined age were studied through the year in a cross section of British herds. Full spermatogenic activity for all populations was first found at 16 months of age though overall growth of the testes continued into middle age. The physiological ability to effect fertile matings is, however, mediated by social forces. Until puberty, growth of the testes is continuous and independent of seasonal factors. Development of the epididymides parallels that of the testes. After puberty, there is a seasonal cycle of growth and regression of the testes and epididymides with maximum weights associated with the mating period (rut) in October/November.

The fallow deer is shown to follow the pattern of other northern temperate deer and to differ in its pattern of spermatogenic activity from tropical deer, such as muntjac, living in Britain.
\end{abstract}

\section{INTRODUCTION}

Little is known of reproductive activity in the male fallow deer beyond general observations on the rut and changes in the antlers (Millais, 1897; de Nahlik, 1959; Taylor Page, 1962; Cadman, 1966) and preliminary observations on thirty-seven testes and epididymides by Chapman \& Chapman (1970). Of the five other feral deer in Britain, data on the male reproductive cycle have been published only for the roe deer, Capreolus capreolus, by Short \& Mann (1966) and Bramley (1970) and for red deer by Lincoln, Youngson \& Short (1970).

Reproduction in male deer in Europe has been studied for roe deer by Stieve (1949), for reindeer, Rangifer tarandus, by Meschaks \& Nordkvist (1962), Borodzin (1966) and Meschaks (1967) and for red deer, Cervus elaphus, by Frankenberger (1953). In North America, testicular activity has been studied in the elk, Cervus canadensis, by Conaway (1952), in the Japanese sika, Cervus nippon, and white tailed deer, Odocoileus virginianus, by Wislocki (1949) and in whitetailed deer by Cheatum \& Morton (1946) and by Robinson, Thomas \& Marburger (1965).

\footnotetext{
* Present address: Royal Zoological Society of Scotland, Scottish National Zoological Park, Edinburgh EH12 6TS.
} 
Most of the studies on the seasonal activity of the testes have been based on a small number of animals. Little attention has been given to changes associated with age or differences between individuals and populations. The present paper presents the results of studies on testes and epididymides obtained at autopsy from fallow deer aged by the method of Chaplin \& White (1969). The results are discussed in relation to our observations on the behaviour patterns associated with the sexual cycle (Chaplin \& White, 1970).

\section{MATERIALS AND METHODS}

The gonads of 206 fallow deer have been examined. Wild animals were obtained from five populations in southern England and one in southern Scotland. Other animals came from two parks in southern England. All animals were obtained within the provisions of the Deer Act of 1963.

The gonads were fixed in $10 \%$ formalin or Bouin's fluid. The epididymis and vas deferens parallel to it were dissected away from the testis and each was weighed. The combined weights of right and left organs are used throughout. Stained sections $(8 \mu \mathrm{m})$ of the testis, caput and cauda epididymidis and vas deferens were examined for spermatogenic activity and the presence of spermatozoa.

The age of each animal was determined using the criteria of Chaplin \& White (1969). In preliminary studies, the animals were considered in five age groups: fawns, yearlings, 2-year-olds, 3-year-olds and animals more than 4 years old. Since no significant differences in gonadal weight or activity were observed for animals of more than 2 years of age, the five groups were reduced to three: fawns, yearlings and adults (all animals more than 24 months old), for the purposes of the present study. The majority of fallow deer are born in June but in the present context it is helpful to regard all animals as having been born on 1st July.

\section{RESULTS}

\section{Changes in the weight of the testes}

The monthly mean and standard deviation of the testes weights in each age class are given in Table 1 . The testes of fawns increased in weight until January. There was no increase over the winter. Growth was resumed in April and the maximum weight in the 2nd year was reached in October and November. A sharp fall in weight occurred from November to December and the testes remained at a low weight until July. The testes of adults increased in weight from July and reached a maximum in September and October. The November mean showed a sharp fall from the peak in October and in succeeding months there was a gradual decrease to a minimum weight in June. These changes are shown in Text-fig. 1. There are significant differences in the mean weights of the testes of each age class in most months. The confidence levels of the differences of these means are given in Table 1.

\section{Changes in the weight of the epididymides}

The monthly mean and standard deviation of epididymal weights in each 
TABLE 1

WEIGHT OF TESTES OF FALLOW DEER

\begin{tabular}{|c|c|c|c|c|c|c|c|c|}
\hline \multirow[b]{2}{*}{ Month } & \multicolumn{2}{|r|}{ Fawns } & \multirow[b]{2}{*}{$\mathbf{P}$} & \multicolumn{2}{|c|}{ rearlings } & \multirow[b]{2}{*}{$\mathbf{P}$} & \multicolumn{2}{|r|}{ Adults } \\
\hline & $\begin{array}{c}\text { Sample } \\
\text { size }\end{array}$ & $\begin{array}{c}\text { Weight of } \\
\text { testes }(\mathrm{g}) \\
\text { Mean } \pm \text { S.D. }\end{array}$ & & $\begin{array}{c}\text { Sample } \\
\text { size }\end{array}$ & $\begin{array}{c}\text { Weight of } \\
\text { testes }(g) \\
\text { Mean } \pm S . D .\end{array}$ & & $\begin{array}{c}\text { Sample } \\
\text { size }\end{array}$ & $\begin{array}{c}\text { Weight of } \\
\text { testes }(g) \\
\text { Mean } \pm S . D .\end{array}$ \\
\hline $\begin{array}{l}\text { July } \\
\text { August } \\
\text { September } \\
\text { October } \\
\text { November } \\
\text { December } \\
\text { January } \\
\text { February } \\
\text { March } \\
\text { April } \\
\text { May } \\
\text { June }\end{array}$ & $\begin{array}{r}0 \\
1 \\
3 \\
0 \\
0 \\
12 \\
14 \\
9 \\
3 \\
5 \\
4 \\
4\end{array}$ & $\begin{array}{l}2.3 \\
2.7 \pm 0.8 \\
\pm \\
5.2 \pm 1.6 \\
6.9 \pm 3.0 \\
6.4 \pm 2.7 \\
5.7 \pm 3.0 \\
12.0 \pm 7.0 \\
16 \cdot 6 \pm 13.1 \\
18.0 \pm 7.0\end{array}$ & $\begin{array}{c}\overline{\bar{E}} \\
>0.01 \\
\overline{\bar{\sigma}} \\
>0.001 \\
>0.001 \\
>0.001 \\
>\overline{0} \\
>0.05 \\
>0.4\end{array}$ & $\begin{array}{r}2 \\
1 \\
4 \\
10 \\
2 \\
4 \\
13 \\
7 \\
0 \\
6 \\
7 \\
3\end{array}$ & $\begin{array}{l}36.0 \pm 0.5 \\
30.9 \\
59 \cdot 6 \pm 20.5 \\
71.2 \pm 24.8 \\
68.2 \pm 39.2 \\
29.9 \pm 4.4 \\
29.0 \pm 2.5 \\
27.0 \pm 2.0 \\
20.1 \pm 3.1 \\
27.9 \pm 10.8 \\
27.4 \pm 3.9\end{array}$ & $\begin{array}{l}>0.001 \\
>0.01 \\
>0.001 \\
>0.9 \\
>0.01 \\
>0.001 \\
>0.001 \\
-\overline{>} \\
>0.02 \\
>0.8 \\
>0.1\end{array}$ & $\begin{array}{r}4 \\
4 \\
24 \\
8 \\
3 \\
6 \\
12 \\
9 \\
6 \\
6 \\
6 \\
5 \\
5\end{array}$ & $\begin{array}{r}23.7 \pm 1.7 \\
72.2 \pm 8.3 \\
112.3 \pm 27.6 \\
133.2 \pm 21.1 \\
80.6 \pm 12.5 \\
66.3 \pm 14 \cdot 1 \\
60.0 \pm 23 \cdot 0 \\
37.9 \pm 13.4 \\
48.2 \pm 17.3 \\
53.8 \pm 26.4 \\
26.2 \pm 5.8 \\
21.0 \pm 3.9\end{array}$ \\
\hline
\end{tabular}

$\boldsymbol{P}=$ confidence level of the difference between means of adjacent age groups.

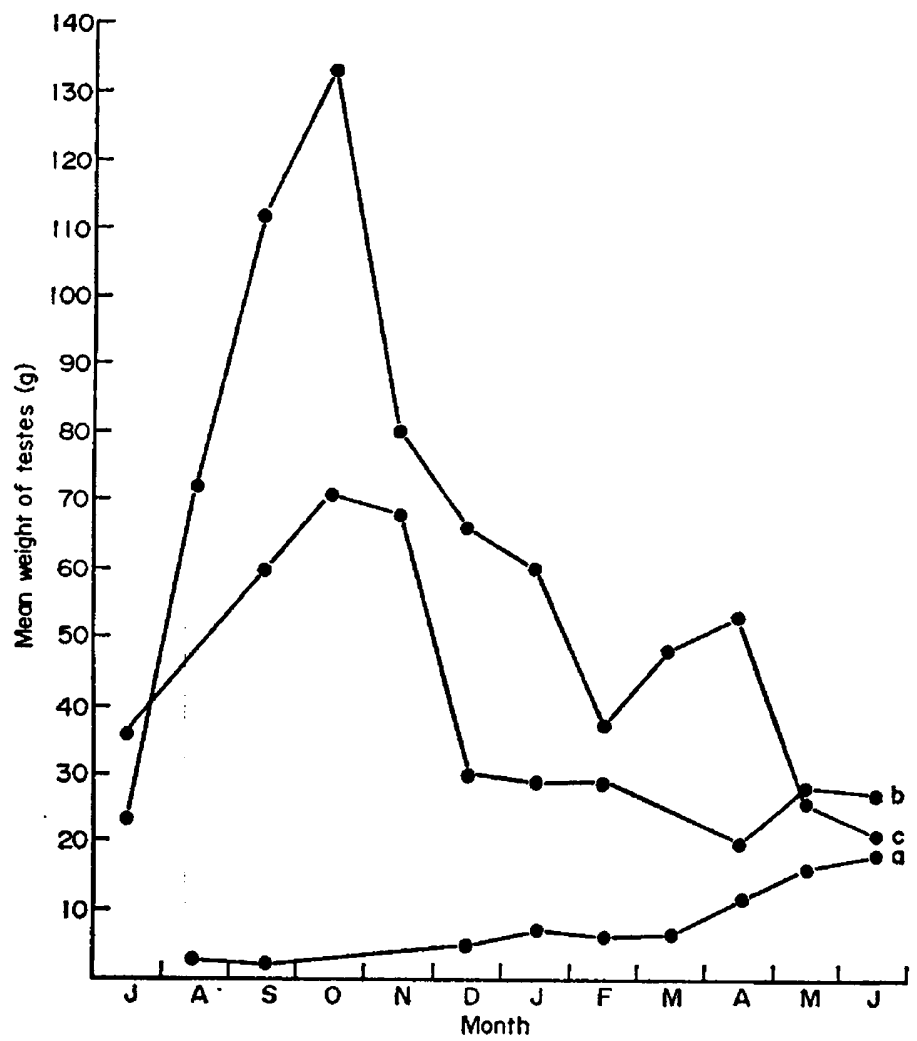

TExT-pig. 1. Seasonal changes in the mean monthly weights of fallow deer testes according to age: (a) fawns, (b) yearlings, (c) adults. 


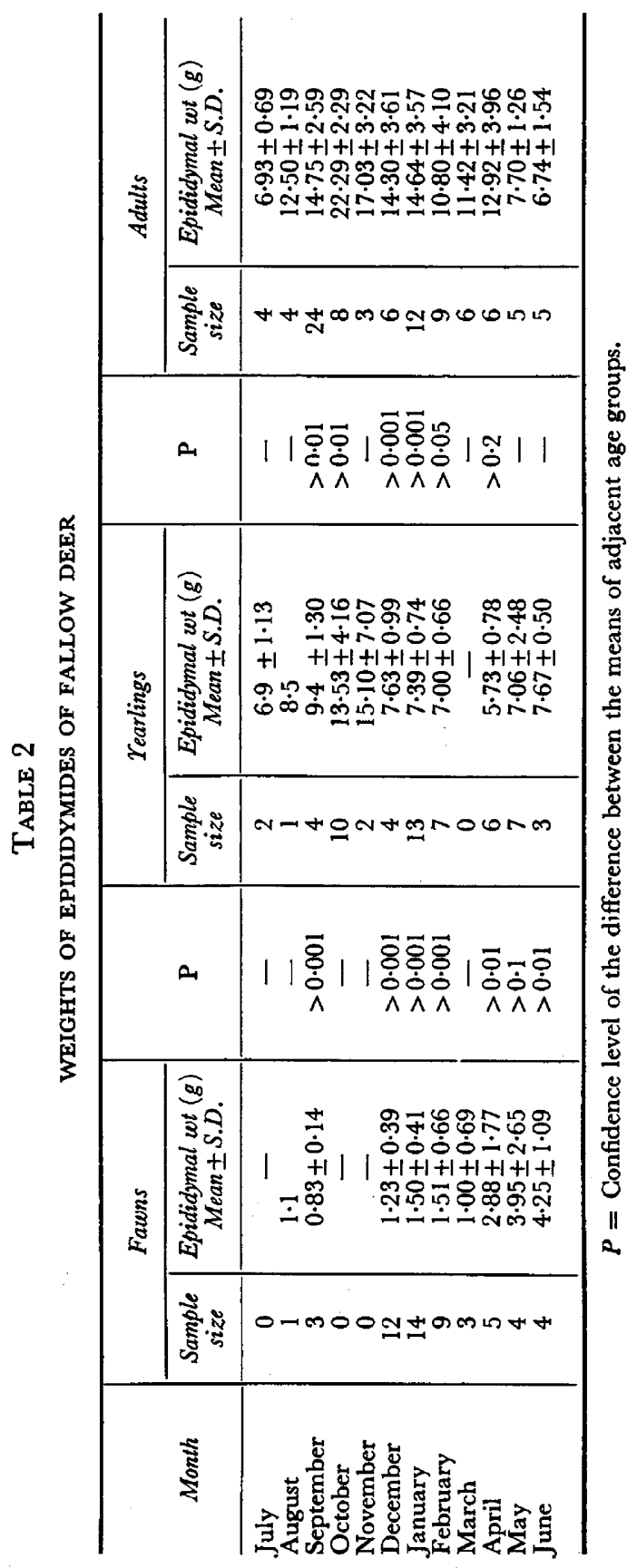


age class are given in Table 2 . There was an increase in weight during the 1st year which continued into the 2nd year. Maximum weights in the 2nd year were reached in October and November. The increase in weight during the 1st year was very slow but, from April, the growth rate increased. There was a sharp decrease in mean weight between November and December in yearlings and the epididymides remained at a low weight until June. In adults, there was a rapid increase in weight from July and the maximum was reached in October. There was then a steady decrease in weight to a minimum in June and July. These changes are shown in Text-fig. 2. There are significant differences in the mean weights of the epididymides of each age class in most months. The confidence levels of the differences of the monthly means are given in Table 2. It will be seen from Text-figs. 1 and 2 that changes in the weight of the epididymides parallel those in the testes.

\section{Spermatogenic activity}

In the testes of a fawn killed in September, the seminiferous tubules were small and lined by a single layer of germinal cells whose cytoplasm filled the

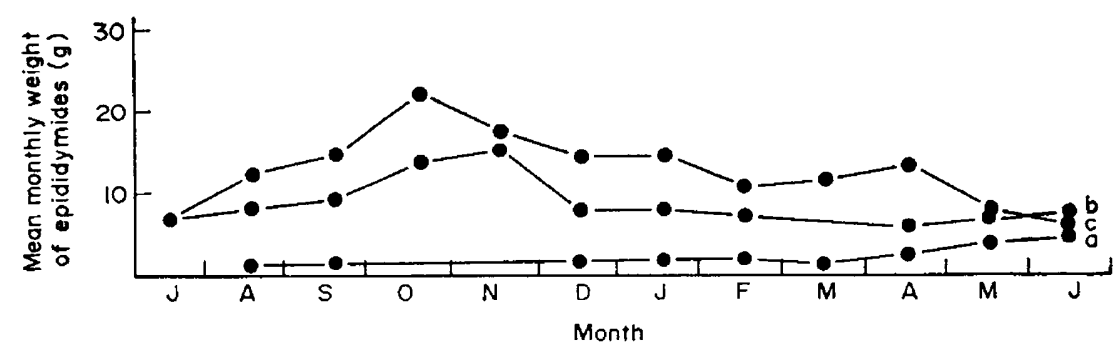

TEXT-FIG. 2. Seasonal changes in the mean monthly weights of fallow deer epididymides according to age: (a) fawns, (b) yearlings, (c) adults.

lumen (P1. 1, Fig. 1). In successive months, there was a gradual enlargement of the tubules and a free lumen developed (Pl. 1, Figs 2 and 3). There were, however, considerable differences in the development of the tubules between individuals on a given date. There was also considerable variation in the onset of pubertal spermatogenesis. The earliest date on which spermatogenesis was found was 1st May but, in May and June, the testes of most fawns contained only spermatocytes. From early July, the testes of these animals, now yearlings, showed full spermatogenic activity (Pl. 1, Fig. 4) which continued until midFebruary. During April and May, in testes of less than $30 \mathrm{~g}$, only spermatocytes were present but heavier testes showed renewed spermatogenesis. In adults also, there was considerable individual variation in the seasonal onset of spermatogenesis. In April and May, the tubules of some adults were active, whilst others in June and July contained only spermatocytes (Pl. 1, Fig. 5). In August, all animals showed full spermatogenic activity (PI. 1, Fig. 6). Active spermatogenesis was found in all testes until the end of March. The apparent continuity of spermatogenesis from one season to the next in some animals was disproved by examination of the contents of the epididymis. In all age groups, there was a cessation of spermatogenesis between successive breeding seasons. 


\section{Spermatozoa in the epididymis}

The epididymal tubules of a fawn killed in September were small and surrounded by thick bands of muscle (Pl. 2, Figs 7 and 8). The lumen was small and lined by columnar epithelium. With growth of the epididymis, there was a progressive enlargement of the tubules and a decline in the relative thickness of the muscle band (Pl. 2, Fig. 9). Growth of the epididymis continued unchecked into the 2nd year.

There was a delay between the onset of spermatogenesis in the testes and the appearance of spermatozoa in the epididymal tubules. Spermatozoa were found in the epididymides of yearlings during the period from September (Pl. 2, Figs 10 and 11) to February. The supply of spermatozoa to the caput epididymidis ceased during February and, although spermatozoa may have persisted in the cauda through May and June, they were absent from the caput.

In all adults, spermatozoa appeared in the epididymis during August and were present until mid-February. In a few animals, spermatozoa were also present in early April. Normally, spermatozoa disappeared from the epididymis soon after spermatogenesis ceased but sometimes a few remained in the cauda, but not in the caput epididymidis, for several months.

\section{DISCUSSION}

The majority of fallow deer fawns in the wild and in semi-natural park conditions are born in June. Although fawns are suckled for at least 6 months, examination of mothers shot in January suggests that there may be little milk available then. Increase in the body weight of males is rapid during the 1st to 3 rd years and slower thereafter. Animals probably reach a maximum body weight by 4 to 6 years. Weights do, however, vary seasonally and also between populations (Chaplin \& White, 1969). Females breed for the first time at about 16 months of age.

Our data show that the weight of the testes and epididymides also increases over several years. There were highly significant differences between the peak weights in fawns, yearlings and adults but no significant differences in weight or activity between 2- and 3-year-old animals, nor between these and older males. The sample of the latter was, however, small.

The spermatogenic activity observed during the rut (October/November) in the testes of animals in their 2nd year (about 16 months) suggests that there is no physiological reason why these animals should not achieve fertile matings. The complex social structure of the herds appears, however, to preclude matings until a male reaches a size and vigour which enables him to establish a territory and attract females to it (Chaplin \& White, 1970). A similar situation was found

\section{EXPLANATION OF PLATE 1 \\ Testes of fallow deer.}

FIG. 1. Testis of fawn killed 4th September. H \& E, $\times 360$.

Fig. 2. Testis of fawn killed 10th December. H \& E, $\times 360$.

FIG. 3. Testis of fawn (approaching 12 months) killed 7 th June. H \& E, $\times 360$.

FIG. 4. Testis of yearling killed 21 st September. H \& E, $\times 360$.

FIG. 5. Testis of adult killed 10th July. H \& E, $\times 360$.

FIG. 6. Testis of adult killed 13th September. H \& E, $\times 360$. 
PLA'I'L I
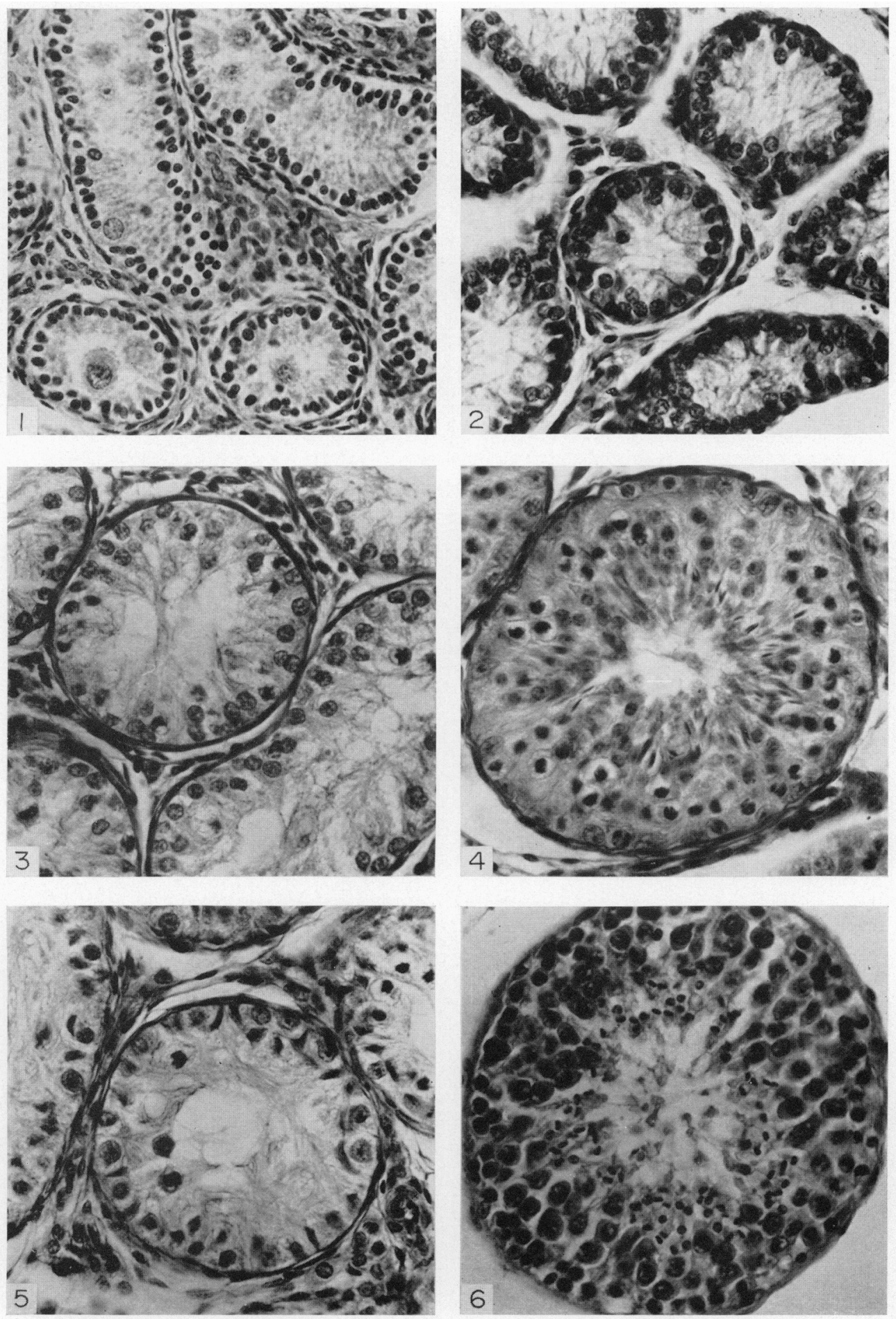

Faring p. 366 
Pl.JPE:
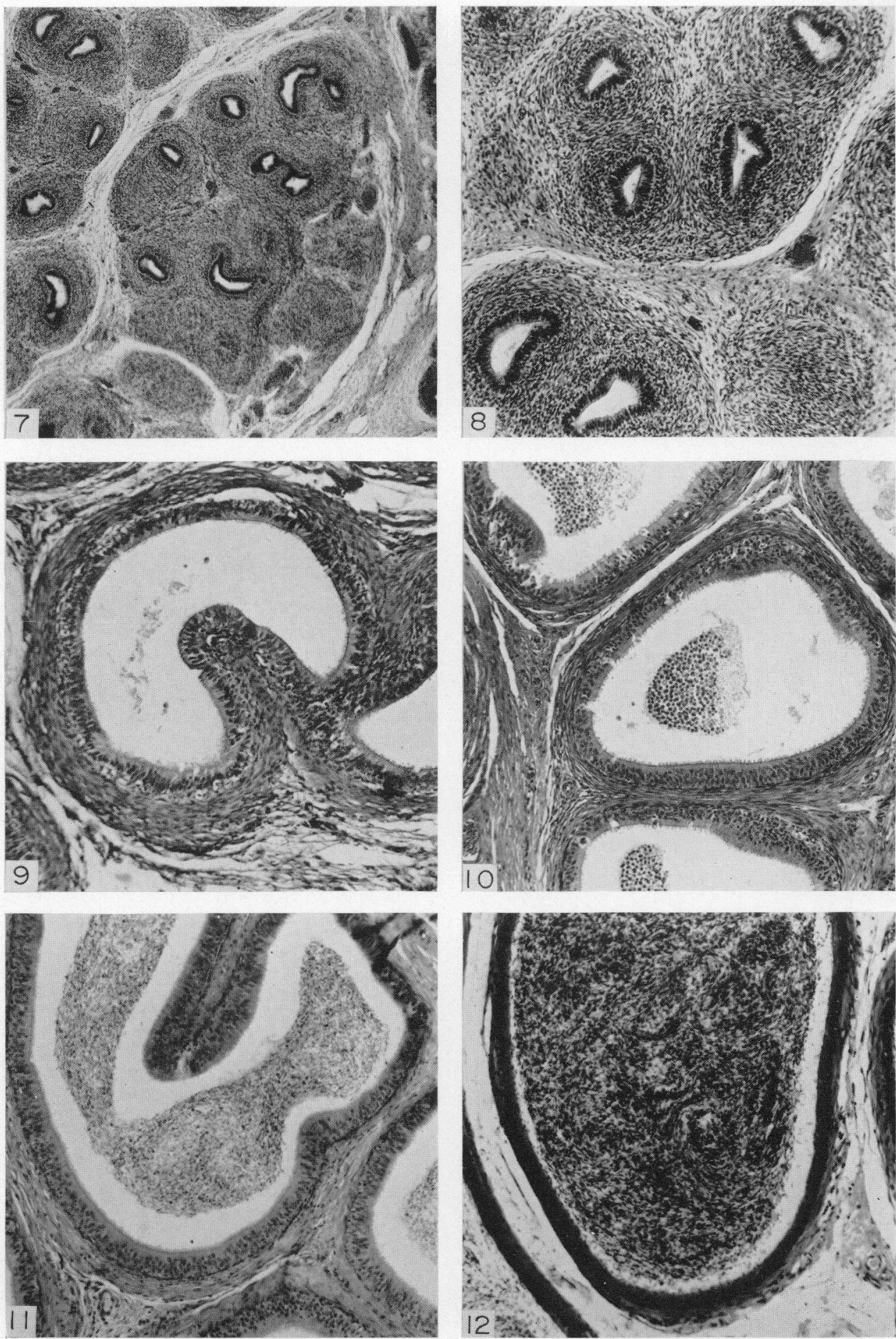

ificing $p .367$ 
in red deer, Cervus elaphus, by Frankenberger (1953). Spermatogenesis was recorded in yearlings during the rut but Frankenberger considered its duration to be short and the amount of spermatozoa produced inadequate for fertile matings. Our own findings suggest that sperm production in fallow deer is adequate.

The cycle of testicular activity in northern deer can generally be correlated with an external environmental stimulus. Jaczewski (1954) and Goss (1968) have demonstrated that day length is such a factor. In the present study, commencement of testicular activity in adults was observed between March and July and peak activity was reached in October and November. The period over which response to the stimulus occurred in individual animals suggests that physical condition may influence the ability to respond. The testicular activity in the fawns, however, contrasted with the seasonal pattern found in the adults, suggesting that pituitary control had not yet been established. Thus, except in late winter, the 1st year of life covers a period of continuous growth of the testes and epididymides. Synchrony with the adult seasonal cycle is achieved about the beginning of the 2nd year of life when spermatogenic activity is initiated.

The seasonal pattern of spermatogenesis found in fallow deer places them in the category of other northern deer such as the red (Frankenberger, 1953), and roe deer (Stieve, 1949; Short \& Mann, 1966). This group of northern deer contrasts with some of the deer from tropical regions such as the chital, Axis axis, and muntjac, Muntiacus sp., in Britain. In muntjac, spermatogenesis is active irrespective of season and thus the male breeding cycle is independent of any seasonal variation in day length (R. E. Chaplin, unpublished studies). The rôle of day length in regulating the sexual cycle of fallow deer and other northern species is shown by the adjustment in the cycle made by animals transferred from Britain and North America to New Zealand (Sadleir, 1969).

The sexual activity of the male is dependent both on spermatogenesis and on seasonal changes in hormone secretion. In red deer, it has been shown that testosterone induces rutting activity (Lincoln et al., 1970). In red deer, as in fallow deer, this is of short duration compared with the length of spermatogenic activity. The majority of matings in fallow deer occur in October and November when rutting activity is at its height. Fertile matings can also occur later in the year when rutting behaviour has subsided (Harrison \& Hyett, 1954; Armstrong, Chaplin, Chapman \& Smith, 1969; Chaplin \& White, 1970) suggesting that high testosterone levels are not essential for fertile matings. These results indicate that spermatogenic activity defines the outside limits within which matings may occur. The weight of the testes steadily rises to a peak during the

\section{EXPLANATION OF PLATE 2}

Epididymides of fallow deer.

FIG. 7. Cauda epididymidis of fawn killed 4 th September. H \& E, $\times 36$.

Frg. 8. Cauda epididymidis of fawn killed 4 th September. H \& E, $\times 90$.

FIG. 9. Cauda epididymidis of fawn killed 7 th June. $H \& E, \times 90$.

Fig. 10. Gauda epididymidis of yearling killed lst September. $\mathbf{H} \& \mathbf{E}, \times 90$.

Fig. 11. Cauda epididymidis of yearling killed 21 st September. $H \&$ E,$\times 90$.

FIG. 12. Cauda epididymidis of adult killed 28 th September. H \& E, $\times 90$. 
rutting season and declines sharply thereafter. This pattern appears to be a good index of the rutting period of a population although the duration of rutting behaviour in individuals is much shorter.

The seasonal cycle of growth, hardening and casting of the antlers shows a temporal correlation with the sexual cycle, but not with spermatogenic activity. Many animals cast their antlers after the onset of renewed seasonal spermatogenesis and not when the tubules are inactive. The work of Goss (1963) and Lincoln et al. (1970) on red deer suggests that the antler cycle is influenced by testosterone secretion.

\section{ACKNOWLEDGMENTS}

We are grateful to their Graces, the Duke and Duchess of Bedford, and their head Verderer, Mr D. Talbot, for study facilities at Woburn. Much valuable material has been collected for us by Mr D. Davis, Mr B. Smith, Mr K. Clark and Mr E. Gwilliam of the Forestry Commission and also by Mr P. Fontaine. For facilities at Richmond Park, we are grateful to the Superintendent and $\mathrm{Mr}$ H. Wonham. Facilities and animals in Epping Forest were kindly made available by the Superintendent, Mr A. Qvist. Some of the specimens were kindly loaned by the Passmore Edwards Museum. The present study was financed by the Natural Environment Research Council.

\section{REFERENCES}

Armstrong, N., Chaplin, R. E., Chapman, D. I. \& Smith, B. (1969) Observations on the reproduction of female wild and park fallow deer (Dama dama) in southern England. 7. Zool., Lond. 158, 27.

Borodzin, E. K. (1966) Age and seasonal changes in the testes of reindeer. Trudy nauchno-issled. Inst. sel'. Khoz. krain Sev. 13, 157.

Bramley, P. S. (1970) Territoriality and reproductive behaviour of roe deer. J. Reprod. Fert. Suppl. $11,43$.

Cadman, W. A. (1966) The fallow deer. Her Majesty's Stationery Office, London.

Chaplin, R. E. \& White, R. W. G. (1969) The use of tooth eruption and wear, body weight and antler characteristics in the age estimation of male wild and park fallow deer (Dama dama). 7. Zool., Lond. 157, 125.

Chaplin, R. E. \& White, R. W. G. (1970) The sexual cycle and associated behaviour patterns in the fallow deer. Deer, 2, 561 .

Chapman, D. I. \& Chapman, N. G. (1970) Preliminary observations on the reproductive cycle of male fallow deer (Dama dama L.). J. Reprod. Fert. 21, 1.

Gheatum, E. L. \& Morton, G. H. (1946) Breeding season of White-tailed deer in New York. F. Wildl. Mgmt, 10, 249.

Conaway, C. (1952) The age of sexual maturity in male elk (Cervus canadensis). 7. Wildl. Mgmt, $16,313$. DE Nahlik, A. (1959) Wild deer, Faber, London.

Frankenberger, ZD. (1953) Pohlavni cyklus jelena. Cslka Morf. 1, 28.

Goss, R. J. (1963) The deciduous nature of deer antlers. In: Mechanisms of Hard Tissue Destruction. Publication no. 75, Amer. Assoc. Advmt Sci., Washington, D.C.

Goss, R. J. (1968) Inhibition of growth and shedding of antlers by sex hormones. Nature, Lond. $220,83$.

Harrison, R.J. \& HyetT, A.R. (1954) The development and growth of the placentomes in the fallow deer (Dama dama L.). 7. Anat. 88, 338.

JAGZEWsKI, Z. (1954) The effect of changes in length of daylight on the growth of antlers in the deer (Cervus elaphus L.) Folia biol., Krakow, 2, 133.

Lincoln, G. A., Youngson, R. W. \& Short, R. V. (1970) The social and sexual behaviour of the red deer stag. J. Reprod. Fert. Suppl. 11, 71.

Meschaks, P. (1967) Seasonal variations of testicular morphology in reindeer. Proc. 5th Congr. Scandinavian Veterinary Society for Sexual Physiology and Sexual Pathology, Stockholm 1966, p. 192. Ed. E. Blom, Statens veterinaere Serumlaboratorium, Statens Serum-institut, Copenhagen, Denmark. 
Meschaks, P. \& Nordxvist, M. (1962) On the sexual cycle in the reindeer male. Acta vet, scand. 3, 151.

Millais, J. G. (1897) British deer and their horns. Sotheran, London.

Robinson, R. M., Thomas, J. W. \& Marburger, R. G. (1965) The reproductive cycle of male whitetailed deer in Central Texas. F. Wildl. Mgmt, 29, 53.

SADLEIR, R. M. F. S. (1969) The ecology of reproduction in wild and domestic mammals. Methuen, London.

ShORT, R. V. \& MANN, T. (1966) The sexual cycle of a seasonally breeding mammal, the roebuck (Capreolus capreolus). F. Reprod. Fert. 12, 337.

Stieve, H. (1949) Anatomisch-biologische Untersuchungen über die Fortpflanzunstätigkeit des europaischen Rehes (Capreolus capreolus capreolus L.). Z. mikrosk. -anat. Forsch. 55, 427.

TAylor Page, F. J. (1962) Fallow deer. In: Animals of Britain, 11. Ed. L. Harrison Mathews. Sunday Times Publications Ltd, London.

WislockI, G. B. (1949) Seasonal changes in the testes, epididymides and seminal vesicles of deer investigated by histochemical methods. Endocrinology, 44, 167. 